
Journal of Scientific and Applied Chemistry

\title{
Synthesis of the BEAC4ND4 Ionophore from $p$-t-Butylcalix[4]arene Carboxylic Acid
}

\author{
Nasriadi Dali ${ }^{a,{ }^{*}}$, Arniah Dali ${ }^{\mathrm{b}}$, Seniwati Dali ${ }^{\mathrm{c}}$, Hilda Ayu Melvi Amalia ${ }^{\mathrm{d}}$ \\ a Department of Chemistry, Faculty of Mathematics and Natural Sciences, Halu Oleo University, Kendari, Indonesia \\ ${ }^{\mathrm{b}}$ Department of Chemistry Education, Faculty of Teacher Training and Education, Halu Oleo University, Indonesia \\ ${ }^{\mathrm{c}}$ Department of Chemistry, Faculty of Mathematics and Natural Sciences, Hasanuddin University, Makassar, Indonesia \\ ${ }^{\mathrm{d}}$ Study Program of Tadris Biology, Faculty of Tarbiyah and Teacher Training, Institut Agama Islam Negeri (IAIN) Kendari, Indonesia \\ * Corresponding author: nasriadidali@ymail.com
}

https://doi.org/10.14710/jksa.23.12.424-431

\section{Article Info}

Article history:

Received: $27^{\text {th }}$ May 2020

Revised: $9^{\text {th }}$ November 2020

Accepted: $29^{\text {th }}$ December 2020

Online: $31^{\text {st }}$ January 2021

Keywords:

BEAC4ND4 ionophore;

chlorination; amidation;

calix[4]arene; carboxylic acid

\begin{abstract}
The BEAC4ND4 ionophore has been successfully synthesized from $p$ - $t$ butylcalix[4]arene carboxylic acid. The BEAC4ND4 ionophore was obtained in two steps of the synthesis reaction. The first step is the chlorination reaction of $p$-t-butylcalix[4]arene carboxylic acid with thionyl chloride in dry benzene solvent. The chlorination reaction product is $p$ - $t$-butylcalix[4]arene acyl chloride in the form of the light brown viscous liquid with a yield of $78.25 \%$ and TLC $\left(\mathrm{SiO}_{2}, \mathrm{CH}_{3} \mathrm{OH}: \mathrm{CH}_{2} \mathrm{Cl}_{2}=1: 1 \mathrm{v} / \mathrm{v}, \mathrm{R}_{\mathrm{f}}=0.65\right)$. The second step is the amidation reaction of ethyl 2-aminoacetate with $p$ - $t$-butylcalix[4]arene acyl chloride in dry tetrahydrofuran solvent. The product of the amidation reaction is $p-t-$ butylcalix[4]arene ethylesteramide or the BEAC4ND4 ionophore in the form of a white solid with the yield of $75.22 \%$, a melting point of $314-316^{\circ} \mathrm{C}$, and TLC $\left(\mathrm{SiO}_{2}, \mathrm{CH}_{3} \mathrm{OH}: \mathrm{CH}_{2} \mathrm{Cl}_{2}=1: 1 \mathrm{v} / \mathrm{v}, \mathrm{R}_{\mathrm{f}}=0.75\right)$.
\end{abstract}

\section{Introduction}

Calix[4]-and-[6]arenes are only slightly soluble in organic solvents. The solubility can be increased by modifying the lower and upper rims of the calix[4]-and[6]arenes. Modification of the lower rim with thioamide can increase the solubility of $p$ - $t$-butylcalix[4]-and[6]arenes in water and dichloromethane [1]. Modification of the top rim with sulfonates can increase the solubility of calix[4]-and-[6]arenes in methanol. Modification can not only increase solubility, but modification can also improve the properties and expand the applications of calix[4]-and-[6] arene. Modifications to the lower rim with ethers, esters, ketones, carboxylic acids, amides, and crown ethers [1] can produce ionophores with binding properties of $\mathrm{Na}^{+}$, $\mathrm{Cs}^{+}, \mathrm{Ca}^{2+}, \mathrm{Mg}^{2+}[2]$, and $\mathrm{Fe}^{3+}, \mathrm{Ni}^{2+}$ cations, which is very selective.

The lower rim of calix[4]-and-[6]arenes by esterification and etherification reactions of the hydroxyl groups on the lower rim are the most popular and extensively studied functionalization. Group modification on the lower rim of calix[4]-and-[6]arenes have been reported by researchers, such as tri(ethoxy carbonyl methoxy)tri(hydroxy)-calix[6]arene [3], hexa(ethylester)calix[6]-arene [4], tetrakis(ethoxy carbonyl methoxy) calix[4]arene, tetra-(carboxylic) calix[4]arene, tetra-(propenyl tetraester)calix[4]arene, and tetra(propenyltetracarboxylicacid)calix[4]-arene [5].

The functionalization of the upper rim of calix[4]and-[6]arenes can be done by modifying $p$ - $t$-butyl with other groups. The $p$-t-butyl group of calix[4]-and[6]arenes can be removed by a Friedel-Crafts dealkylation reaction [6]. Furthermore, the new group may be bound to the para position through electrophilic aromatic substitution reactions. For example, the Friedel-Crafts dealkylation reaction of $p-t-$ butylcalix[4]arene gives $p$-H-calix[4]arene. Electrophilic aromatic substitution reactions of $p-\mathrm{H}-$ calix[4]arene produces para-substituted calix[4]arenes with various para-substituents. The reaction of $p-H-$ 
calix[4]arene with formaldehyde and dimethylamine (Mannich Reaction) gives p-aminomethylcalix[4]arene, which can be converted into the corresponding quaternary ammonium compounds by reaction with MeI. Attack of the ammonium salts by a nucleophile affords $p$-Nu-methylcalix[4]arenes. The $p$ $\mathrm{H}$-calix[4]arene is alkylated with allyl bromide in the presence of a base to give the tetraallyl ether, which undergoes the Claisen rearrangement to give $p$ allylcalix[4]arene [7]. So, the combination of the lower rim modification reactions with some protectiondeprotection strategies allows one, two, three, or four substituents (same or different) to be attached on the para-positions of calix[4]arenes.

Modification of functional groups of the upper and the lower rim of calix[4]-and-[6]arenes can produce ionophores $[3,6]$. The $\mathrm{OH}$ group's modification reactions of the lower rim with ethylester produce BEC4ND1 and BEC6ND1 [2] ionophores. Modification reactions of the ethylester group of the lower rim with carboxylic acid produce BCAC4ND2 [8] and BCAC6ND2 [9] ionophores. Modification reactions of the $t$-butyl group of the upper rim with a tetramer or hexamer produces an ionophore that is selective to the cations of $\mathrm{Rb}, \mathrm{Sr}, \mathrm{Cs}$, alkali metals, and alkaline earth metals [10].

This study aims to synthesize BEAC4ND4 ionophore from $p$-t-butylcalix[4]arene carboxylic acid. The BEAC4ND4 ionophore can be synthesized in two steps of the synthesis reaction. The first step is the chlorination reaction of $p$ - $t$-butylcalix[4]arene carboxylic acid with thionyl chloride in dry benzene solvent. The second step is the amidation reaction of ethyl 2-aminoacetate with $p$ - $t$-butylcalix[4]arene acyl chloride in dry tetrahydrofuran solvent.

\section{Methodology}

\subsection{Tools}

The tools used are rotary vacuum evaporator (BUCHI Rotavapor $^{\mathrm{TM}}$ series R-300), digital melting point apparatus (Electrothermal series IA9100), desiccator, analytical balance (Explorer Ohaus), measuring cup (Pyrex), chemical beaker (Pyrex), chamber, ball coolers, thermometers $\left(100^{\circ} \mathrm{C}\right)$, heating mantles, funnels, and a set of reflux devices consisting of $100 \mathrm{~mL}$ three-neck round bottom flask. Spectrometers used are the FTIR Shimadzu series Prestige-21 and FTNMR Jeol series JNM-MY500.

\subsection{Materials}

The materials used are the raw material, $p$ - $t$ butylcalix[4]arene carboxylic acid (synthesized), benzene (Merck), thionyl chloride (Merck), pyridine (Merck), tetrahydrofuran (THF) (Merck), ethyl ester amines (Merck), triethylamine (Merck), nitrogen gas (commercial), methanol (Merck), dichloromethane (Merck), anhydrous sodium sulfate $\left(\mathrm{Na}_{2} \mathrm{SO}_{4}\right)$ (Merck), double distilled water (Onelab Waterone), and TLC plate. All reagents were in analytical grade.

\subsection{Synthesis of the BEAC4ND4 Ionophore}

p-t-Butylcalix[4]arene carboxylic acid $(0.44 \mathrm{~g}, 0.5$ mmol) in dry benzene $(25 \mathrm{~mL})$ was added $\mathrm{SOCl}_{2}(5 \mathrm{~mL})$ and 3 drops of pyridine. The mixture was stirred and refluxed under nitrogen at room temperature for 8 hours. The mixture was TLC tested every 2 hours to control the reaction results. The solution of $\mathrm{p}^{-t^{-}}$ butylcalix[4]arene acyl chloride (bp. $182^{\circ} \mathrm{C}$ ) was separated from thionyl chloride (bp. $74.6^{\circ} \mathrm{C}$ ) by distillation. The solution of $p$-t-butylcalix[4]arene acyl chloride is unstable, so this solution is used immediately without further purification.

The solution of $p$-t-butylcalix[4]arene acyl chloride $(0.23 \mathrm{~g}, 0.2409 \mathrm{mmol})$ in dry THF $(5 \mathrm{~mL})$ was added dropwise to a solution of ethyl 2-aminoacetate $(0.21 \mathrm{~mL}$, $1.8328 \mathrm{mmol}$ ) and trimethylamine (0.21 mL, $2.227 \mathrm{mmol}$ ) in dry THF (10 mL) at atmospheric conditions nitrogen. The mixture was stirred with a magnetic stirrer for 24 hours at room temperature while flowing nitrogen gas. Every 8 hours, the mixture tested TLC to control the reaction results. Furthermore, the mixture was filtered, and the filtrate was concentrated with rotavapor at $66^{\circ} \mathrm{C}$. The residue was dissolved in dichloromethane $(10 \mathrm{~mL})$, and the solution is washed with cold water $\left(-5^{\circ} \mathrm{C}\right)(10$ $\mathrm{mL})$. Furthermore, the solution was dried with anhydrous $\mathrm{Na}_{2} \mathrm{SO}_{4}$. The product solution was filtered, and the solvent was evaporated with rotavapor at $39.6^{\circ} \mathrm{C}$. The solids that formed were recrystallized with methanol and dichloromethane. The white solid formed is BEAC4ND4 ionophore. Furthermore, the BEAC4ND4 ionophore is dried in the desiccator and then characterized by TLC, melting point, FTIR, and FTNMR $\left({ }^{1} \mathrm{H},{ }^{13} \mathrm{C}\right)$. The temperatures used for the ${ }^{1} \mathrm{H}-\mathrm{NMR}$ and ${ }^{13} \mathrm{C}-$ NMR measurements were $408^{\circ} \mathrm{C}$ and $406.5^{\circ} \mathrm{C}$, respectively.

\subsection{Determination of the BEAC4ND4 Ionophore Structure}

The BEAC4ND4 ionophore structure was determined using spectroscopic techniques, namely FTIR and FTNMR ${ }^{1-D}\left({ }^{1} \mathrm{H}\right.$ and $\left.{ }^{13} \mathrm{C}\right)$. The physical data of the BEAC4ND4 ionophore are yield of 75,22\%; mp 314$316^{\circ} \mathrm{C} ; \mathrm{TLC}\left(\mathrm{SiO}_{2}, \mathrm{CH}_{3} \mathrm{OH}: \mathrm{CH}_{2} \mathrm{Cl}_{2}=1: 1 \mathrm{v} / \mathrm{v}, \mathrm{Rf}=0.75\right)$. The spectrum data of FTIR, ${ }^{1} \mathrm{H}$ and ${ }^{13} \mathrm{C}-\mathrm{NMR}$ of the BEAC4ND4 ionophore are presented in the following description. FTIR $(\mathrm{KBr}) v_{\text {maks }}\left(\mathrm{cm}^{-1}\right): 1749.44$ (esters $\mathrm{C}=\mathrm{O}$ stretch), 1120.64 (C-O-C stretch in dialkyl ethers), 1242.16 (C-O-C stretch in alkyl aryl ethers), 1066.64 (RC-O stretch in alkyl aryl ethers), 3055.24 and 3024.38 (CH stretch of unsaturated aromatic), 1633.71 (aromatic $\mathrm{C}=\mathrm{C}$ stretch), 1201.65 (aromatic C-O stretch), 817.82 and 783.1 ( $\mathrm{CH}$ out-of-plane deformation of disubstituted para aromatic), 3446.79 ( $\mathrm{NH}$ stretch of secondary amides), 1645.28 ( $\mathrm{C}=\mathrm{O}$ stretch of secondary amides) (amide I band), 1479.4 (C-N stretch of secondary amides) (amide II band), 2960.73, 2906.73, and 2866.22 (CH stretch of $\left(\mathrm{CH}_{3}\right)_{3} \mathrm{C}$ saturated aliphatic), $1392.61(\mathrm{CH}$ stretch of $\mathrm{CH}_{3}$ aliphatic), 1429.25 ( $\mathrm{CH}$ stretch of $\mathrm{CH}_{2}$ aliphatic); ${ }^{1} \mathrm{H}-\mathrm{NMR}\left(500 \mathrm{MHz}, \mathrm{CDCl}_{3}\right) \delta_{\mathrm{H}}(\mathrm{ppm}): 7.0380$ $[(\mathrm{s}, 1 \mathrm{H})(\mathrm{ArH}-22 / 24)], 4.3273\left[(\mathrm{~s}, 2 \mathrm{H})\left(\mathrm{CH}_{2} \mathrm{O}-2 "\right)\right]$, $5.9762[(\mathrm{~s}, 1 \mathrm{H})(\mathrm{NH}-1 \wedge)], 2.5419\left[(\mathrm{~s}, 2 \mathrm{H})\left(\mathrm{CH}_{2} \mathrm{NH}-1^{\#}\right)\right]$, 
$3.0034\left[(\mathrm{q}, 2 \mathrm{H}, J=6.7 \mathrm{~Hz})\left(\mathrm{OCH}_{2} \mathrm{CH}_{3}-1^{*}\right)\right], 1.4423[(\mathrm{t}, 3 \mathrm{H}$, $\left.J=6.7 \mathrm{~Hz})\left(\mathrm{OCH}_{2} \mathrm{CH}_{3}-2 *\right)\right], 4.2428[(\mathrm{~d}, 2 \mathrm{H}, J=12.9 \mathrm{~Hz})$ $\left.\left(\mathrm{ArCH}_{2} \mathrm{Ar}-2 \mathrm{~b}\right)\right], 3.4808\left[(\mathrm{~d}, 2 \mathrm{H}, J=12.9 \mathrm{~Hz})\left(\mathrm{ArCH}_{2} \mathrm{Ar}-\right.\right.$

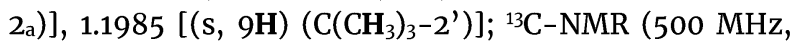
$\left.\mathrm{CDCl}_{3}\right) \delta_{\mathrm{C}}(\mathrm{ppm}): \mathbf{1 7 2 . 1 5 3 7}$ [(CO amides) $\left.\left(\mathbf{C}-\mathbf{1}^{\prime \prime}\right)\right], 42.4278$ $\left[\mathrm{CH}_{2}\right.$ amides $\left.)\left(\mathbf{C}-\mathbf{1}^{\#}\right)\right], 170.7319$ [(CO esters) $\left.\left(\mathbf{C}-2^{\#}\right)\right]$, 62.3785 [ $\left(\mathrm{CH}_{2}\right.$ esters $\left.)\left(\mathbf{C}-1^{*}\right)\right], 11.5713\left[\left(\mathrm{CH}_{3}\right.\right.$ esters) $(\mathbf{C}-$ $\left.2^{*}\right)$ ], 146.8248 [(CO aryl) (C-25)], 144.5451 [(C-para aryl) (C-23)], 127.8531 [(C-ortho aryl) $(\mathbf{C}-1 / \mathbf{C}-21)], 126.0980$ [(C-meta aryl) (C-22/C-24)], $73.5713\left[\left(\mathrm{ArOCH}_{2^{-}}\right)(\mathbf{C}-\right.$

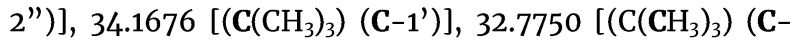
$\left.\left.2^{\prime}\right)\right]$, and 31.5637 [( $\left.\left.\mathrm{ArCH}_{2} \mathrm{Ar}\right)(\mathbf{C}-2 / \mathrm{C}-20)\right]$. The position of the chemical shift value of ${ }^{1} \mathrm{H}$ and ${ }^{13} \mathrm{C}$ - NMR in the carbon framework of the BEAC4ND4 ionophore can be seen in Figure 1.
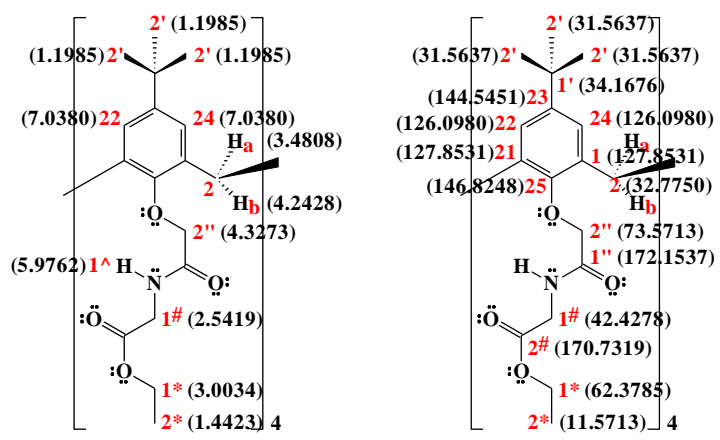

Figure 1. The position of the chemical shift value of ${ }^{1} \mathrm{H}-$ NMR (left) and ${ }^{13} \mathrm{C}$-NMR (right) in the carbon framework of the BEAC4ND4 ionophore

\section{Results and Discussion}

The first step of the synthesis reaction of the BEAC4ND4 ionophore is the chlorination reaction of $p-t$ butylcalix[4]arene carboxylic acid with thionyl chloride in dry benzene (Figure 2). The $p$-t-butylcalix[4]arene acyl chloride was obtained in the form of the light brown viscous liquid with the yield of $78.25 \%$ and $\mathrm{TLC}\left(\mathrm{SiO}_{2}\right.$, $\left.\mathrm{CH}_{3} \mathrm{OH}: \mathrm{CH}_{2} \mathrm{Cl}_{2}=1: 1 \mathrm{v} / \mathrm{v}, \mathrm{R}_{\mathrm{f}}=0.65\right) . \mathrm{R}_{\mathrm{f}}$ value of the synthesis product (0.65) is lower than the value of reactant $R_{f}(0.91)$ (Figure 3$)$. This is consistent with the expected where the synthesis product has a higher polarity than the reactant. The $p$-t-butylcalix[4]arene acyl chloride is not analyzed spectroscopically because the compound is highly reactive to water vapor.

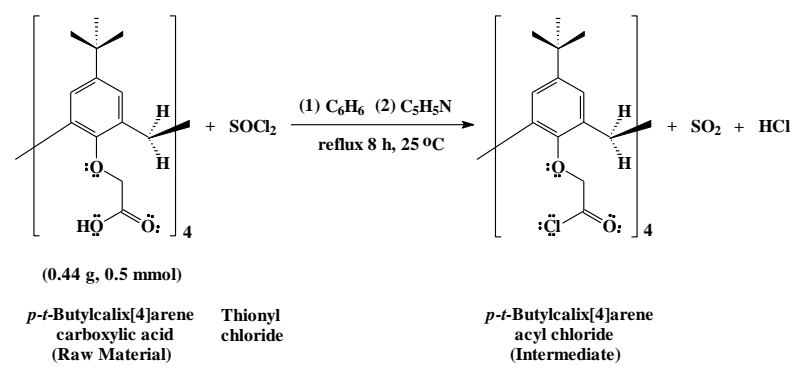

Figure 2. The chlorination reaction of $p-t$ butylcalix[4]arene carboxylic acid with thionyl chloride to form of the $p$ - $t$-butylcalix[4]arene acyl chloride

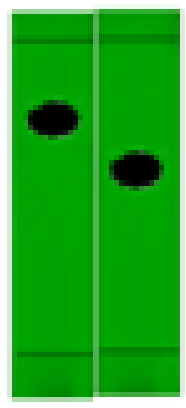

(a) (b)

Figure 3. $\mathrm{TLC}\left(\mathrm{SiO}_{2}, \mathrm{CH}_{3} \mathrm{OH}: \mathrm{CH}_{2} \mathrm{Cl}_{2}=1: 1 \mathrm{v} / \mathrm{v}\right)$ test results: (a) $p$-t-butylcalix[4]arene carboxylic acid $\left(\mathrm{R}_{\mathrm{f}}=\right.$ 0.91); (b) $p$-t-butylcalix[4]arene acyl chloride $\left(\mathrm{R}_{\mathrm{f}}=\right.$ $0.65)$

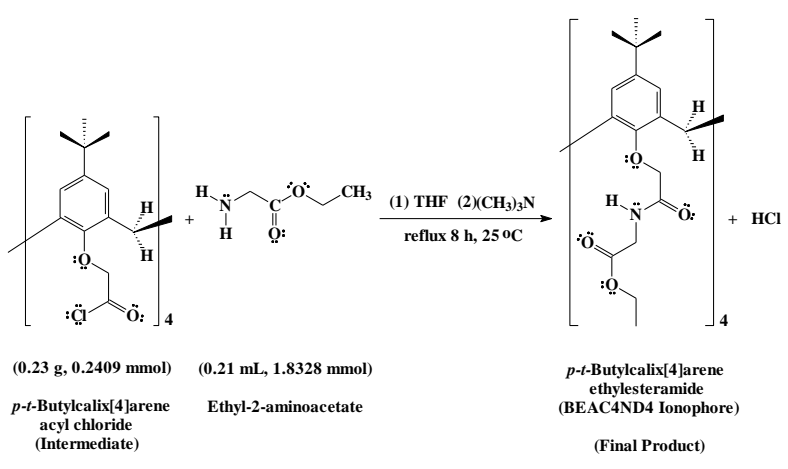

Figure 4. The amidation reaction of the $p-t$ butylcalix[4]arene acyl chloride with ethyl 2aminoacetate to form the BEAC4ND4 ionophore

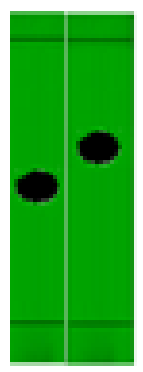

(a) (b)

Figure 5. TLC $\left(\mathrm{SiO}_{2}, \mathrm{CH}_{3} \mathrm{OH}: \mathrm{CH}_{2} \mathrm{Cl}_{2}=1: 1 \mathrm{v} / \mathrm{v}\right)$ test results: (a) $p$ - $t$-butylcalix[4]arene acyl chloride $\left(\mathrm{R}_{\mathrm{f}}=\right.$ 0.65); (b) BEAC4ND4 ionophore $\left(R_{f}=0.75\right)$

The second step is the amidation reaction of the $p$ $t$-butylcalix[4]arene acyl chloride with ethyl 2aminoacetate in dry tetrahydrofuran to form the $p-t-$ butylcalix[4]arene ethylesteramide or the BEAC4ND4 ionophore (Figure 4).

The synthesis product of the BEAC4ND4 ionophore was shaped white solid with a yield of $75.22 \%$, a melting point of $314-316^{\circ} \mathrm{C}$, and TLC $\left(\mathrm{SiO}_{2}, \mathrm{CH}_{3} \mathrm{OH}: \mathrm{CH}_{2} \mathrm{Cl}_{2}=1: 1\right.$ $\left.\mathrm{v} / \mathrm{v}, \mathrm{R}_{\mathrm{f}}=0.75\right)$. $\mathrm{R}_{\mathrm{f}}$ value of the synthesis product $(0.75)$ is higher than the value of reactant $R_{f}(0.65)$ (Figure 5). This is consistent with the expected where the BEAC4ND4 ionophore has a lower polarity than the reactant. 

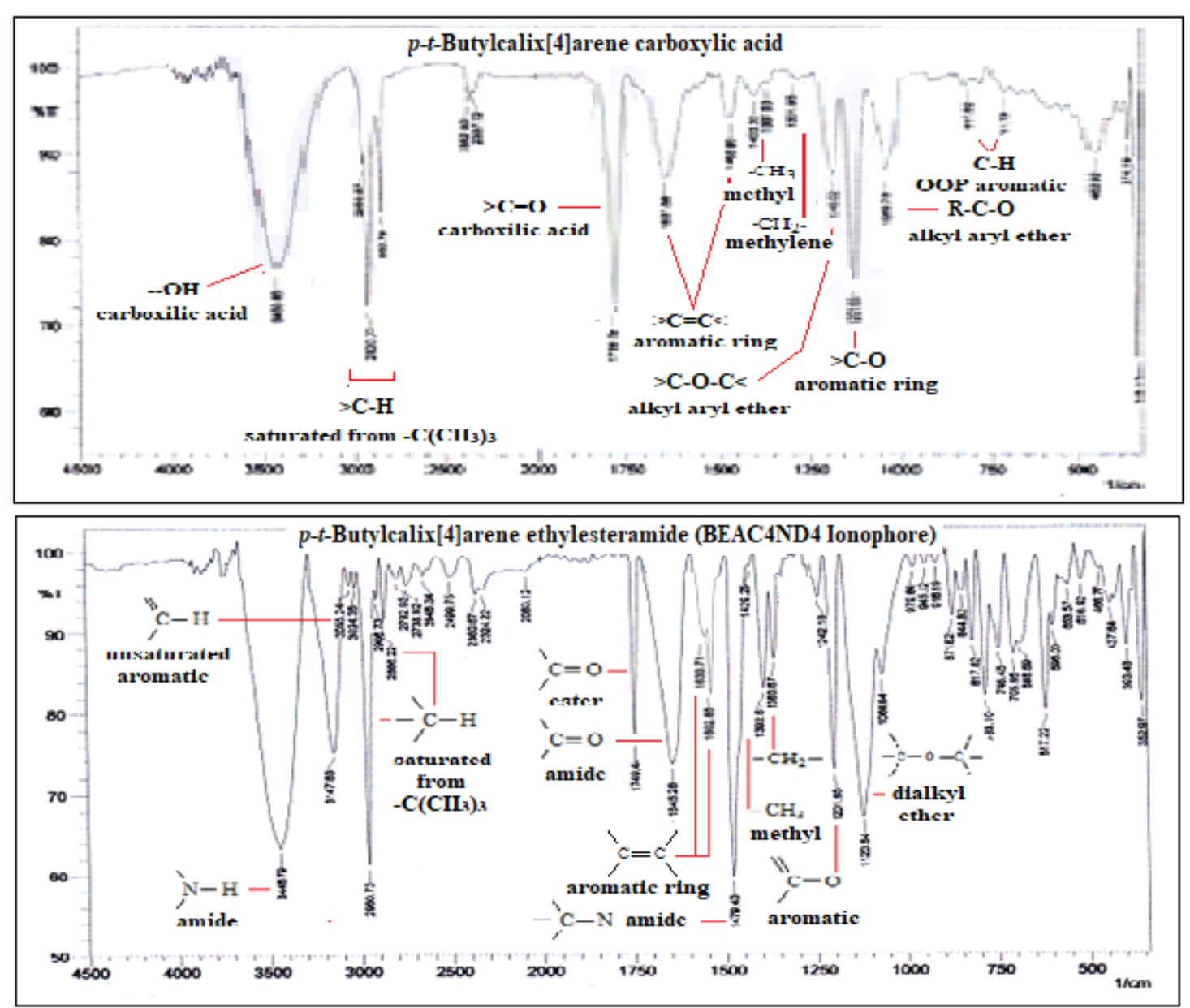

Figure 6. Comparison of the FTIR spectrum of $p$ - $t$-butylcalix[4]arene carboxylic acid (raw material) (above) and the BEAC4ND4 ionophore (product) (under)

Table 1. Interpretation of the FTIR spectrum of the $p-t$ butylcalix[4]arene carboxylic acid (raw material) and the BEAC4ND4 ionophore (product)

\begin{tabular}{|c|c|c|c|c|c|}
\hline \multirow[t]{2}{*}{ No } & \multicolumn{2}{|c|}{$\begin{array}{l}\text { Frequency }\left(\mathrm{cm}^{-1}\right) \text { and } \\
\text { Intensities }\end{array}$} & \multirow{2}{*}{$\begin{array}{c}\text { Frequency } \\
\text { Ranges }\left(\mathrm{cm}^{-1}\right) \\
\text { and Intensities* }\end{array}$} & \multirow[t]{2}{*}{ Group or Class } & \multirow[t]{2}{*}{ Remarks } \\
\hline & $\begin{array}{c}\text { Raw } \\
\text { Material }\end{array}$ & $\begin{array}{l}\text { BEAC4ND4 } \\
\text { Ionophore }\end{array}$ & & & \\
\hline 1 & $\begin{array}{c}3450.65 \\
\text { (vs) }\end{array}$ & - & $3400-2400(\mathrm{~s})$ & & OH stretch \\
\hline 2 & $\begin{array}{l}1739.79 \\
\text { (vs) }\end{array}$ & - & $1730-1700$ (vs) & $\begin{array}{c}\text { Carboxylic } \\
\text { Acids RCOOH }\end{array}$ & $\mathrm{C}=\mathrm{O}$ stretch \\
\hline 3 & - & $1749.44(\mathrm{~s})$ & $1765-1720$ (vs) & Esters RCOOR' & $\mathrm{C}=\mathrm{O}$ stretch \\
\hline 4 & - & 1120.64 (vs) & $1140-1110$ (vs) & ROR' & $\begin{array}{l}\mathrm{C}-\mathrm{O}-\mathrm{C} \text { stretch in } \\
\text { dialkyl ethers }\end{array}$ \\
\hline 5 & $\begin{array}{l}1244.09 \\
(\mathrm{~s})\end{array}$ & $1242.16(\mathrm{~s})$ & $1280-1220(\mathrm{~s})$ & & $\begin{array}{l}\mathrm{C}-\mathrm{O}-\mathrm{C} \text { stretch in } \\
\text { alkyl aryl ethers }\end{array}$ \\
\hline 6 & $\begin{array}{l}1089.78 \\
(\mathrm{~s})\end{array}$ & $1066.64(\mathrm{~s})$ & $1075-1020(\mathrm{~s})$ & & $\begin{array}{l}\mathrm{R}-\mathrm{C}-\mathrm{O} \text { stretch in } \\
\text { alkyl aryl ethers }\end{array}$ \\
\hline 7 & - & $3055.24(w)$ & $3159-3000(\mathrm{~m})$ & Aromatic ArH & $\mathrm{C}-\mathrm{H}$ unsaturated \\
\hline 8 & - & $3024.38(w)$ & & & \\
\hline 9 & $\begin{array}{l}1637.56 \\
(\mathrm{~s})\end{array}$ & $1633.71(w)$ & $1630-1430(v)$ & & $\begin{array}{c}\mathrm{C}=\mathrm{C} \text { aromatic ring } \\
\text { stretching }\end{array}$ \\
\hline 10 & $\begin{array}{c}1201.65 \\
\text { (vs) }\end{array}$ & 1201.65 (vs) & $1300-1000(\mathrm{~s})$ & & $\begin{array}{c}\mathrm{C}-\mathrm{O} \text { aromatic ring } \\
\text { stretching }\end{array}$ \\
\hline 11 & $\begin{array}{c}817.82 \\
(w)\end{array}$ & $817.82(\mathrm{~m})$ & $900-650(\mathrm{~s})$ & & $\begin{array}{l}\text { Out-of-plane } \mathrm{C}-\mathrm{H} \\
\text { deformation } 1,4^{-} \\
\text {disubstituted para }\end{array}$ \\
\hline 12 & $\begin{array}{l}711.73 \\
(w)\end{array}$ & $783.1(\mathrm{~s})$ & & & \\
\hline 13 & - & 3446.79 (vs) & $3460-3400(\mathrm{~m})$ & Amides CONHR & $\begin{array}{c}\mathrm{N}-\mathrm{H} \text { stretch of } \\
\text { secondary amides }\end{array}$ \\
\hline 14 & - & $1645.28(\mathrm{~s})$ & $1680-1640$ (vs) & & $\begin{array}{l}\mathrm{C}=\mathrm{O} \text { stretch of } \\
\text { secondary amides } \\
\text { (amide I band) }\end{array}$ \\
\hline
\end{tabular}

\begin{tabular}{|c|c|c|c|c|c|}
\hline 15 & - & 1479.4 (vs) & $1550-1460(\mathrm{~s})$ & & $\begin{array}{l}\mathrm{C}-\mathrm{N} \text { stretch of } \\
\text { secondary amides } \\
\text { (amide II bands) }\end{array}$ \\
\hline 16 & $\begin{array}{l}2956.87 \\
\text { (w) }\end{array}$ & 2960.73 (vs) & \multirow[t]{3}{*}{$2970-2850(\mathrm{~s})$} & \multirow[t]{3}{*}{ Aliphatic RH } & \multirow{3}{*}{$\begin{array}{l}\text { C-H saturated } \\
\text { stretching from } \\
\quad\left(\mathrm{CH}_{3}\right)_{3} \mathrm{C}-\end{array}$} \\
\hline 17 & $\begin{array}{l}2920.23 \\
\text { (vs) }\end{array}$ & $2906.73(w)$ & & & \\
\hline 18 & $\begin{array}{c}2850.79 \\
(\mathrm{~s})\end{array}$ & $2866.22(w)$ & & & \\
\hline 19 & $\begin{array}{c}1367.53 \\
(\mathrm{w})\end{array}$ & $1392.61(\mathrm{~m})$ & $1450-1375(\mathrm{~s})$ & $\begin{array}{c}t- \\
\operatorname{Butyl}\left(\mathrm{CH}_{3}\right)_{3} \mathrm{C}-\end{array}$ & $\begin{array}{c}\mathrm{C}-\mathrm{H} \text { stretch from } \\
\mathrm{CH}_{3-}\end{array}$ \\
\hline 20 & $\begin{array}{c}1465.90 \\
(\mathrm{w})\end{array}$ & $1429.25(\mathrm{~m})$ & $1485-1450(\mathrm{~m})$ & $\begin{array}{l}\text { Methylene - } \\
\mathrm{CH}_{2^{-}}\end{array}$ & $\begin{array}{l}\mathrm{C}-\mathrm{H} \text { stretch from } \\
\qquad-\mathrm{CH}_{2-}^{-}\end{array}$ \\
\hline
\end{tabular}

-Notes: vs = very strong; $\mathrm{v}=$ variable; $\mathrm{s}=$ strong; $\mathrm{m}=$ medium; $\mathrm{w}=$ weak

*Sources: [11, 12, 13]

Comparison and interpretation of the FTIR spectrum of $p$ - $t$-butylcalix[4]arene carboxylic acid (raw material) and the BEAC4ND4 ionophore (product) are shown in Figure 6 and Table 1. The FTIR spectrum of the $p$-t-butylcalix[4]arene carboxylic acid (raw material) shows strong absorption bands at $3450.65 \mathrm{~cm}^{-1} 1739.79$ $\mathrm{cm}^{-1}$ derived from the $\mathrm{OH}$ and $\mathrm{C}=\mathrm{O}$ stretches of carboxylic acids. These two strong absorption bands do not appear in the FTIR spectrum of the BEAC4ND4 ionophore. In contrast, the FTIR spectrum of the BEAC4ND4 ionophore showed strong absorption bands at $1749.44 \mathrm{~cm}^{-1}(\mathrm{C}=\mathrm{O}$ stretch), $1120.64 \mathrm{~cm}^{-1}$ (C-O-C stretch in dialkyl ethers), $3446.79 \mathrm{~cm}^{-1}(\mathrm{~N}-\mathrm{H}$ stretch of secondary amides), $1645.28 \mathrm{~cm}^{-1}$ ( $\mathrm{C}=\mathrm{O}$ stretch of secondary amides [amide I 
band]), and $1479.4 \mathrm{~cm}^{-1}$ (C-N stretch of secondary amides [amide II bands]). These five strong absorption bands do not appear in the FTIR spectrum of the raw material. This shows that $\mathrm{OH}$ and $\mathrm{C}=\mathrm{O}$ groups of carboxylic acids in the raw material have been changed to $\mathrm{C}=\mathrm{O}$ esters, $\mathrm{C}-\mathrm{O}-\mathrm{C}$ ether, $\mathrm{C}=\mathrm{O}$ amide, and $\mathrm{C}-\mathrm{N}$ amide groups in the BEAC4ND4 ionophore during the synthesis reaction.

This synthesis reaction's success is also supported by the ${ }^{1} \mathrm{H}-\mathrm{NMR}$ spectrum data of the synthesis product. Comparison and interpretation of the ${ }^{1} \mathrm{H}-\mathrm{NMR}$ spectrum of $p$-t-butylcalix[4]arene carboxylic acid (raw material) and the BEAC4ND4 ionophore (product) are shown in Figure 7 and Table 2.
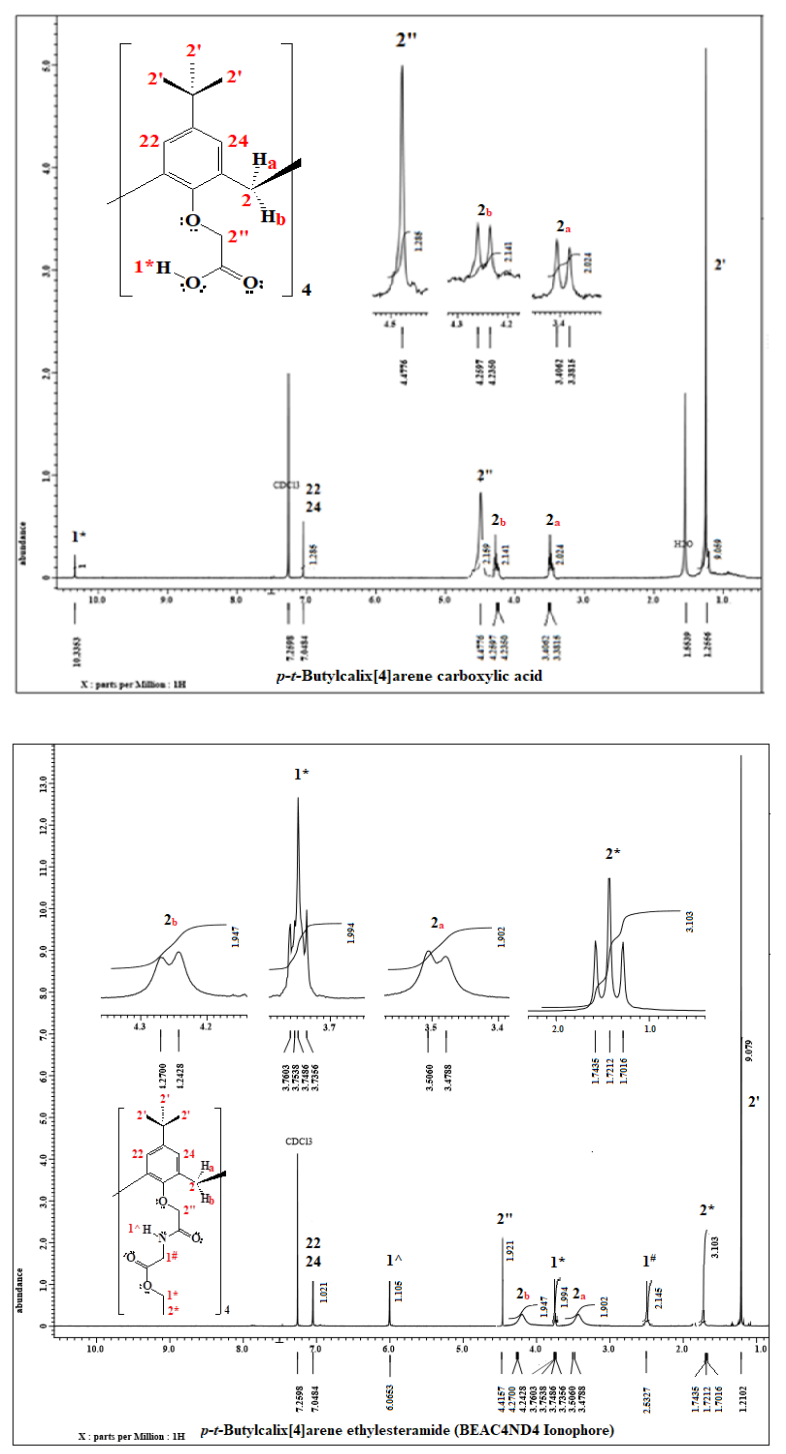

Figure 7. Comparison of the ${ }^{1} \mathrm{H}-\mathrm{NMR}$ spectrum of $p-t-$ butylcalix[4]arene carboxylic acid (raw material) (above) and the BEAC4ND4 ionophore (product) (below)
Table 2. Interpretation of the NMR $\left({ }^{1} \mathrm{H},{ }^{13} \mathrm{C}\right)$ spectrum of the $p$ - $t$-butylcalix[4]arene carboxylic acid (raw material) and the BEAC4ND4 ionophore (product)

\begin{tabular}{|c|c|c|c|c|c|c|c|}
\hline \multirow{2}{*}{$\begin{array}{c}\text { C } \\
\text { Positio } \\
\text { n }\end{array}$} & \multicolumn{2}{|c|}{$\delta_{\mathrm{C}}(\mathrm{ppm})$} & \multirow[t]{2}{*}{ Groups } & \multirow{2}{*}{$\begin{array}{c}\mathrm{H} \\
\text { Positio } \\
\mathrm{n}\end{array}$} & \multicolumn{2}{|c|}{$\delta_{\mathrm{H}}(\mathrm{ppm})$} & \multirow[t]{2}{*}{ Groups } \\
\hline & $\begin{array}{c}\text { Raw } \\
\text { Material }\end{array}$ & $\begin{array}{c}\text { BEAC4ND } \\
4 \\
\text { Ionophore }\end{array}$ & & & $\begin{array}{c}\text { Raw } \\
\text { Materia } \\
\text { l }\end{array}$ & $\begin{array}{c}\text { BEAC4ND } \\
4 \\
\text { Ionophore }\end{array}$ & \\
\hline 1,21 & 127.8691 & 127.8531 & C- $o$ aryl & & - & - & - \\
\hline 22,24 & 126.1236 & 126.0980 & C- $m$ aryl & 22,24 & $\begin{array}{l}7.0484 \\
(2 \mathrm{H}, s)\end{array}$ & $\begin{array}{l}7.0380 \\
(2 \mathrm{H}, s)\end{array}$ & ArH \\
\hline 23 & 144.5516 & 144.5451 & C-p aryl & & - & - & - \\
\hline 25 & $\begin{array}{c}146.850 \\
3\end{array}$ & 146.8248 & CO aryl & & - & - & - \\
\hline $1^{\prime}$ & 34.1932 & 34.1676 & $\mathbf{C}\left(\mathrm{CH}_{3}\right)_{3}$ & & - & - & - \\
\hline $2^{\prime}$ & 31.5892 & 31.5637 & $\mathrm{C}\left(\mathrm{CH}_{3}\right)_{3}$ & $2^{\prime}$ & $\begin{array}{l}1.2556 \\
(9 \mathrm{H}, \mathrm{s})\end{array}$ & $\begin{array}{l}1.1985 \\
(9 \mathrm{H}, \mathrm{s})\end{array}$ & $\mathrm{C}\left(\mathrm{CH}_{3}\right)_{3}$ \\
\hline \multirow[t]{2}{*}{$22_{a}, 2 b$} & 30.2348 & 32.7750 & $\mathrm{ArCH}_{2} \mathrm{Ar}$ & $2 b$ & $\begin{array}{c}3.3939 \\
(1 \mathrm{H}, d, J \\
=12.9 \\
\mathrm{~Hz})\end{array}$ & $\begin{array}{c}3.4808 \\
(1 \mathrm{H}, d, J= \\
12.9 \mathrm{~Hz})\end{array}$ & $\mathrm{ArCH}_{2} \mathrm{Ar}$ \\
\hline & & & & $2 a$ & $\begin{array}{c}4.2474 \\
(\mathbf{1 H}, d, J \\
=12.9 \\
\mathrm{~Hz})\end{array}$ & $\begin{array}{c}4.2428 \\
(1 \mathrm{H}, d, J= \\
12.9 \mathrm{~Hz})\end{array}$ & $\mathrm{ArCH}_{2} \mathrm{Ar}$ \\
\hline \multirow[t]{2}{*}{ 1" } & - & 172.1537 & $\begin{array}{c}\mathbf{C}=0 \\
\text { amides }\end{array}$ & 1" & - & - & - \\
\hline & 170.3153 & - & $\begin{array}{c}\mathbf{C}=0 \\
\text { carboxyli } \\
\text { c acids }\end{array}$ & & $\begin{array}{c}10.3353 \\
(1 \mathrm{H}, s)\end{array}$ & - & $\mathrm{CO}_{2} \mathrm{H}$ \\
\hline \multirow[t]{2}{*}{ 2" } & 73.1351 & 73.5713 & $\mathrm{ArOCH}_{2-}$ & 2" & $\begin{array}{l}4.4776 \\
(2 \mathrm{H}, \mathrm{s})\end{array}$ & $\begin{array}{l}4.3273 \\
(2 \mathrm{H}, s)\end{array}$ & $\mathrm{CH}_{2} \mathrm{O}$ \\
\hline & & & & $1^{\wedge}$ & - & $\begin{array}{l}5.9762 \\
(1 \mathrm{H}, s)\end{array}$ & NH \\
\hline $1^{\#}$ & - & 42.4278 & $\mathrm{CH}_{2} \mathrm{NH}$ & $1^{\#}$ & - & $\begin{array}{l}2.5419 \\
(2 \mathrm{H}, \mathrm{s})\end{array}$ & $\mathrm{CH}_{2} \mathrm{NH}$ \\
\hline $2^{\#}$ & - & 170.7319 & $\begin{array}{l}\mathbf{C}=0 \\
\text { esters }\end{array}$ & & - & - & - \\
\hline $1^{*}$ & - & 62.3785 & $\mathrm{OCH}_{2} \mathrm{CH}_{3}$ & $1^{*}$ & - & $\begin{array}{c}3.0034 \\
(2 \mathrm{H}, q, J= \\
6.7 \mathrm{~Hz})\end{array}$ & $\begin{array}{c}\mathrm{OCH}_{2} \mathrm{CH} \\
3\end{array}$ \\
\hline $2^{*}$ & - & 11.5713 & $\mathrm{OCH}_{2} \mathrm{CH}_{3}$ & $2^{*}$ & - & $\begin{array}{c}1.4423 \\
(3 \mathrm{H}, t, J= \\
6.7 \mathrm{~Hz})\end{array}$ & $\begin{array}{c}\mathrm{OCH}_{2} \mathrm{CH} \\
3\end{array}$ \\
\hline
\end{tabular}

The ${ }^{1} \mathrm{H}$-NMR spectrum of the $p$ - $t$-butylcalix[4]arene carboxylic acid (raw material) shows the presence of a signal at $\delta_{\mathrm{H}} 10.3353 \mathrm{ppm}(\mathbf{1 H}, \mathrm{s})$ derived from carboxylic acid protons $\left(\mathrm{OH}-1^{*}\right)$. This signal is no longer found in the ${ }^{1} \mathrm{H}-\mathrm{NMR}$ spectrum of the BEAC4ND4 ionophore. In contrast, the ${ }^{1} \mathrm{H}-\mathrm{NMR}$ spectrum of the BEAC4ND4 ionophore shows the presence of several signals not found in the ${ }^{1} \mathrm{H}-\mathrm{NMR}$ spectrum of the raw material. These signals are the amide (NH-1 $\Lambda$ ) proton signal, which appears at $\delta_{\mathrm{H}} 5.9762 \mathrm{ppm}(1 \mathrm{H}, \mathrm{s})$, the methylene amide $\left(\mathrm{CH}_{2} \mathrm{NH}-1^{\#}\right)$ proton signal, which appears at $\delta_{\mathrm{H}}$ $2.5419 \mathrm{ppm}(2 \mathrm{H}, s)$, the methylene ethoxy $\left(\mathrm{OCH}_{2} \mathrm{CH}_{3}-1 *\right)$ proton signal which appears at $\delta_{\mathrm{H}} 3.0034 \mathrm{ppm}(2 \mathrm{H}, q, J=$ $6.7 \mathrm{~Hz})$, and the methyl ethoxy $\left(\mathrm{OCH}_{2} \mathrm{CH}_{3}-2^{*}\right)$ proton signal which appears at $\delta_{\mathrm{H}} 1.4423 \mathrm{ppm}(3 \mathrm{H}, t, J=6.7 \mathrm{~Hz})$. This shows that the $\mathrm{OH}$ group of raw material has been transformed into ethylesteramide in the BEAC4ND4 ionophore. Furthermore, the proton signals that appear on the BEAC4ND4 ionophore are the same as the raw material proton signals. These signals are the aryl (ArH$22 / 24)$ proton signal that appears at $\delta_{\mathrm{H}} 7.0380 \mathrm{ppm}(1 \mathrm{H}$, s), methylene methoxy $\left(\mathrm{CH}_{2} \mathrm{O}-2 "\right)$ proton signal that appears at $\delta_{\mathrm{H}} 4.3273 \mathrm{ppm}(2 \mathrm{H}, \mathrm{s})$, the methylene bridge proton signal, which is split into two, namely the methylene $\left(\mathrm{ArCH}_{2} \mathrm{Ar}-\mathrm{2}_{\mathrm{a}}\right)$ bridge proton signal that appears at $\delta_{\mathrm{H}} 4.2428 \mathrm{ppm}(2 \mathrm{H}, d, J=12.9 \mathrm{~Hz})$ and the exo methylene $\left(\mathrm{ArCH}_{2} \mathrm{Ar}-2 \mathrm{~b}\right)$ bridge proton signal which appears at $\delta_{\mathrm{H}} 3.4808 \mathrm{ppm}(2 \mathrm{H}, d, J=12.9 \mathrm{~Hz})$, and the 
highest-intensity singlet proton signal that appear at $\delta_{\mathrm{H}}$ $1.1985 \mathrm{ppm}(9 \mathrm{H}, \mathrm{s})$ originates from tert-butyl $\left(\mathrm{C}\left(\mathrm{CH}_{3}\right)_{3}-\right.$ $\left.2^{\prime}\right)$. Thus, the signals that appear in the range of $\delta_{\mathrm{H}} \mathrm{O}-$ $7.0 \mathrm{ppm}$ in the ${ }^{1} \mathrm{H}-\mathrm{NMR}$ spectrum of the synthesized product are in accordance with the proton character of the BEAC4ND4 ionophore (Figure 8).

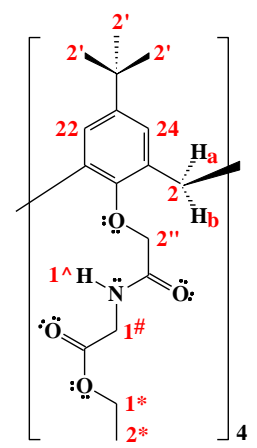

Figure 8. The proton character of the BEAC4ND4 ionophore

Comparison and interpretation of the ${ }^{13} \mathrm{C}-\mathrm{NMR}$ spectrum of $p$ - $t$-butylcalix[4]arene carboxylic acid (raw material) and the BEAC4ND4 ionophore (product) are shown in Figure 9 and Table 2. The analysis of the synthesis product with the ${ }^{13} \mathrm{C}-\mathrm{NMR}$ spectrometer also corroborated the results of the FTIR and ${ }^{1} \mathrm{H}-\mathrm{NMR}$ spectrum analysis above. The ${ }^{13} \mathrm{C}-\mathrm{NMR}$ spectrum of the BEAC4ND4 ionophore showed a signal at $\delta_{\mathrm{C}} 172.1537 \mathrm{ppm}$ derived from carbon $\mathbf{C}-1$ " which binds to the $\mathbf{C}=0$ amide group. Whereas the $\mathrm{C}-1$ " carbon signal in the ${ }^{13} \mathrm{C}-\mathrm{NMR}$ spectrum of the raw material appears as a $\mathbf{C}=\mathrm{O}$ carboxylic

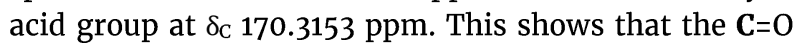
carboxylic acid group on the raw material has been changed to the $\mathbf{C}=\mathrm{O}$ amide group on the BEAC4ND4 ionophore. Furthermore, the ${ }^{13} \mathrm{C}-\mathrm{NMR}$ spectrum of the BEAC4ND4 ionophore shows the presence of several signals not found in the ${ }^{13} \mathrm{C}-\mathrm{NMR}$ spectrum of the raw material. These signals are the methylene amide $\left(\mathbf{C H}_{2} \mathrm{NH}{ }^{\#}\right) \mathbf{C}^{-1}{ }^{\#}$ signal, which appears at $\delta_{\mathrm{C}} \mathbf{4 2 . 4 2 7 8}$ ppm, the carbonyl ester ( $\mathbf{C}=0$ ester) $\mathbf{C}-2^{\#}$ signal, which appears at $\delta_{\mathrm{C}} 170.7319 \mathrm{ppm}$, the methylene ethoxy $\left(\mathrm{OCH}_{2} \mathrm{CH}_{3}-1^{*}\right) \mathbf{C}-1^{*}$ signal, which appears at $\delta_{\mathrm{C}} 62.3785$ ppm, and the methyl ethoxy $\left(\mathrm{OCH}_{2} \mathrm{CH}_{3}-2 *\right) \mathbf{C}-2 *$ signal

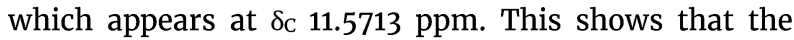
carbon framework of the BEAC4ND4 ionophore has increased by four atoms of $\mathrm{C}$.

The other carbon signals in the ${ }^{13} \mathrm{C}-\mathrm{NMR}$ spectrum of the BEAC4ND4 ionophore are the same as the raw material carbon signals. These signals are the signals of aryl carbon (C-aryl) atoms, scattered into four values of

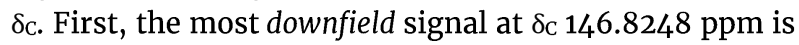
the $\mathbf{C}-25$ (C-aryl) atomic signal, which binds oxygen directly to the $\mathrm{OCH}_{2} \mathrm{CONHR}$ group. Second, the signal

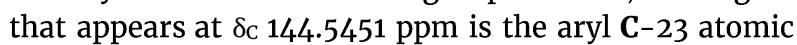
signal at the para (C-para aryl), which binds to the $t$ butyl group. Third, the signal that appears at $\delta_{\mathrm{C}} 127.8531$ ppm is the aryl $\mathbf{C}-1 / \mathbf{C}-21$ atomic signal at the ortho $(\mathbf{C}-$ ortho aryl) position. Fourth, the signal that appears at $\delta_{\mathrm{C}}$ $126.0980 \mathrm{ppm}$ is the aryl $\mathbf{C}-22 / \mathbf{C}-24$ atomic signal at the meta (C-meta aryl) position. Furthermore, the signals of carbon atoms appearing more upfield are signals from alkyl groups. The signal that appears at $\delta \mathrm{c} 73.5713 \mathrm{ppm}$ is the C-2" atomic signal from methylene aryl ether carbon $\left(\mathrm{ArOCH}_{2}{ }^{-}\right)$. The signal that appears at $\delta \mathrm{c} 34.1676$ ppm is the $\mathbf{C}-\mathbf{1}^{\prime}$ atomic signal from $t$-butyl quarternary carbon $\left[-\mathbf{C}\left(\mathrm{CH}_{3}\right)_{3}\right]$. The signal that appears at $\delta_{\mathrm{C}} 32.7750$ $\mathrm{ppm}$ is the $(\mathbf{C}-2 / \mathbf{C}-20)$ atomic signal from the methylene bridge carbon $\left(\mathrm{ArCH}_{2} \mathrm{Ar}\right)$. The signal that appears at $\delta_{\mathrm{C}}$ $31.5637 \mathrm{ppm}$ is the $\mathrm{C}-2$ ' atomic signal from t-butyl methyl carbon $\left[-\mathrm{C}\left(\mathrm{CH}_{3}\right)_{3}\right]$. Thus, the signals that appear in the range of $\delta_{\mathrm{C}} \mathrm{O}-180.0 \mathrm{ppm}$ in the ${ }^{13} \mathrm{C}-\mathrm{NMR}$ spectrum of the synthesis product is in accordance with the carbon framework of the $p$-t-butylcalix[4]arene ethyl ester amide or the BEAC4ND4 ionophore (Figure 10).
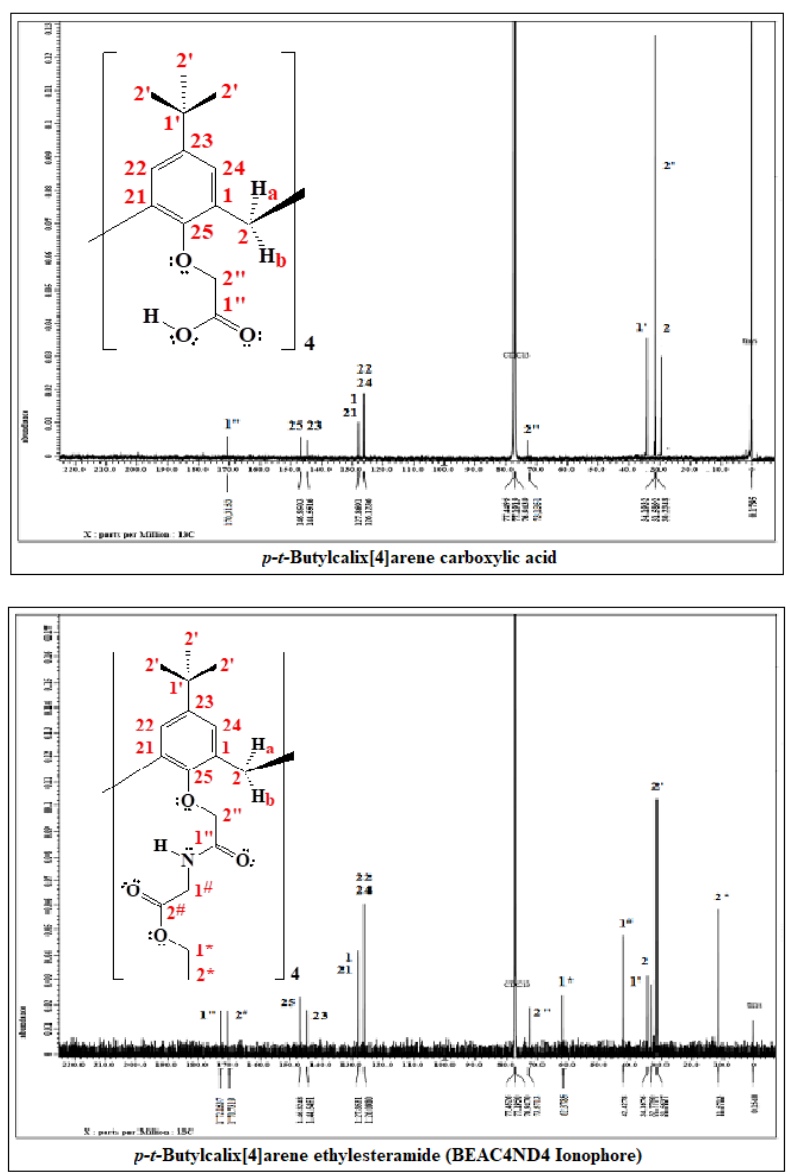

Figure 9. Comparison of the ${ }^{13} \mathrm{C}-\mathrm{NMR}$ spectrum of $p-t$ butylcalix[4]arene carboxylic acid (raw material) (above) and the BEAC4ND4 ionophore (product) (under)<smiles>CCOC(=O)CNC(=O)COc1c(C)cc(C(C)C)cc1CC</smiles>

Figure 10. The carbon framework of the BEAC4ND4 ionophore 
The conformational form of the BEAC4ND4 ionophore can be easily identified by their ${ }^{1} \mathrm{H}$ and ${ }^{13} \mathrm{C}-$ NMR spectrum, mainly through the bridging methylene groups' patterns. If the chemical shift of the methylene proton is close to $(4.2 \pm 1 \mathrm{ppm})$ and $(3.4 \pm 1 \mathrm{ppm})$, then the conformations of calix[4]arenes are cone $[14,15,16$, 17]. The ${ }^{1} \mathrm{H}-\mathrm{NMR}$ spectrum of the BEAC4ND4 ionophore (Table 2) shows that the methylene bridge proton $\left(\mathrm{ArCH}_{2} \mathrm{Ar}\right)$ absorption band appears as two doublets on $\delta_{\mathrm{H}}$ 4.2428 ppm and $\delta_{\mathrm{H}} 3.4808 \mathrm{ppm}$. These absorption bands' pattern indicates that the conformation of the BEAC4ND4 ionophore is a cone (Figure 11). If the chemical shift for the methylene carbon is near $31 \mathrm{ppm}$, two adjacent aryl groups are synced to each other [14, 15, $16,17]$. The ${ }^{13} \mathrm{C}-\mathrm{NMR}$ spectrum of the BEAC4ND4 ionophore (Figure 9) shows that the carbon absorption band from the methylene bridge group $\left(\mathrm{ArCH}_{2} \mathrm{Ar}\right)$ appear at $\delta \mathrm{c} 32.7750 \mathrm{ppm}(\approx 31 \mathrm{ppm})$. This means that the orientation of two adjacent aryl groups is syn (a plot) to each other (Figure 11).

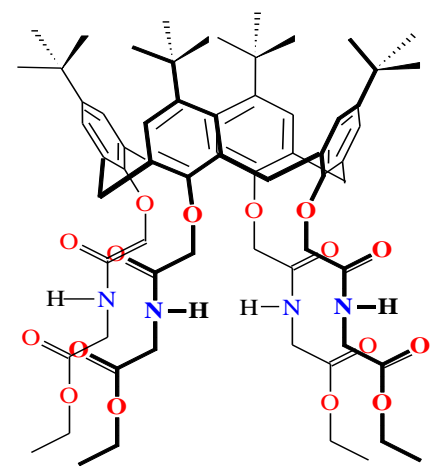

Figure 11. Cone conformation of the BEAC4ND4 ionophore

\section{Conclusion}

The BEAC4ND4 ionophore has been successfully synthesized from $p-t$-butylcalix[4]arene carboxylic acid. The BEAC4ND4 ionophore was obtained in two steps of the synthesis reaction, namely the chlorination and amidation reaction. The chlorination reaction product is $p$-t-butylcalix[4]arene acyl chloride in the form of the light brown viscous liquid with a yield of $78.25 \%$ and TLC $\left(\mathrm{SiO}_{2}, \mathrm{CH}_{3} \mathrm{OH}: \mathrm{CH}_{2} \mathrm{Cl}_{2}=1: 1 \mathrm{v} / \mathrm{v}, \mathrm{R}_{\mathrm{f}}=0.65\right)$. The product of the amidation reaction is $p$-t-butylcalix[4]arene ethylesteramide or the BEAC4ND4 ionophore in the form of a white solid with the yield of $75.22 \%$, a melting point of $314-316^{\circ} \mathrm{C}$, and TLC $\left(\mathrm{SiO}_{2}, \mathrm{CH}_{3} \mathrm{OH}: \mathrm{CH}_{2} \mathrm{Cl}_{2}=1: 1 \mathrm{v} / \mathrm{v}, \mathrm{R}_{\mathrm{f}}\right.$ $=0.75$ ).

\section{Acknowledgments}

The author would like to thank the Integrated Laboratory Chemistry Department staff, Faculty of Mathematics and Natural Sciences, Hasanuddin University Makassar, and Chemical Research Center of Indonesian Institute of Sciences to analyze samples for FTIR, ${ }^{1} \mathrm{H}$, and ${ }^{13} \mathrm{C}-\mathrm{NMR}$ spectrometer.

\section{References}

[1] Françoise Arnaud-Neu, Geraldine Barrett, Denis Corry, Suzanne Cremin, George Ferguson, John F.
Gallagher, Stephen J. Harris, M. Anthony McKervey, Marie-Jose Schwing-Weill, Cation complexation by chemically modified calixarenes. Part 10. Thioamide derivatives of p-tert-butylcalix[4]-, [5]- and [6]arenes with selectivity for copper, silver, cadmium and lead. X-Ray molecular structures of calix[4]arene thioamide-lead(II) and calix[4]arene amide-copper(II) complexes, Journal of the Chemical Society, Perkin Transactions 2, 3, (1997), 575-580 https://doi.org/10.1039/A605417J

[2] Peter L. H. M. Cobben, Richard J. M. Egberink, Johan G. Bomer, Piet Bergveld, Willem Verboom, David N. Reinhoudt, Transduction of selective recognition of heavy metal ions by chemically modified field effect transistors (CHEMFETs), Journal of the American Chemical Society, 114, 26, (1992), 10573-10582 https://doi.org/10.1021/ja00052a063

[3] Nasriadi Dali, Abd. Wahid Wahab, Firdaus, Maming, Sintesis5,11,17,23,29,35-Heksa-p-tert-Butil37,39,41-Tri(Etoksikarbonilmetoksi)-38,40,42Trihidroksi-Kaliks[6]Arena dari p-tertButilkaliks[6]Arena, Jurnal Kimia \& Pendidikan Kimia, 1, 2, (2012), 110-115

[4] Nasriadi Dali, Abd Wahid Wahab, Firdaus Firdaus, Maming Maming, Sintesis Heksa-p-tertButilheksaesterkaliks [6] Arena dari p-tertButilkaliks [6] Arena, Al-Kimia, 3, 1, (2015), 103-109

[5] Triana Kusumaningsih, Jumina Jumina, Dwi Siswanta, Mustofa Mustofa, Synthesis of Tetra-pPropenyltetraestercalix 4]arene and Tetra- $p$ Propenyltetracarboxylicacidcalix[4]arene from $p-t-$ Butylphenol, Indonesian Journal of Chemistry, 10, 1, (2010), 122-126 https://doi.org/10.22146/ijc.21491

[6] Vandna Arora, Har Mohindra Chawla, Suneel Pratap Singh, Calixarenes as sensor materials for recognition and separation of metal ions, Arkivoc, 2007, 2, (2007), 172-200 http://dx.doi.org/10.3998/ark.5550190.0008.205

[7] C David Gutsche, Calixarenes Revisited, Royal Society of Chemistry, London, 1983

[8] Nasriadi Dali, Arniah Dali, Synthesis of the BCAC4ND2 Ionophore from pt-Butylcalix [4] arene Ethylester, Akta Kimia Indonesia, 5, 1, (2020), 33-42 https://dx.doi.org/10.12962/j25493736.v5i1.6711

[9] Nasriadi Dali, Abd Wahid Wahab, Firdaus, Maming, Muhammad Nurdin, Synthesis of Hexa (p-tertbutyl) hexa (carboxylic acid) calix [6] arene from Hexa (p-tert-butyl) hexa (ethyl ester) calix [6] arene, International Journal of ChemTech Research, 9, (2016), 486-490

[10] Damien W. M. Arrigan, Gyula Svehla, Stephen J. Harris, M. Anthony McKervey, Use of calixarenes as modifiers of carbon paste electrodes for voltammetric analysis, Electroanalysis, 6, 2, (1994), 97-106 https://doi.org/10.1002/elan.1140060205

[11] William Kemp, Organic Spectroscopy, 3rd ed., Macmillan International Higher Education, 1991

[12] Joseph B. Lambert, Herbert F. Shurvell, David A. Lightner, Robert Graham Cooks, Organic Structural Spectroscopy, Prentice Hall, 1998

[13] Hardjono Sastrohamidjojo, Spektroskopi resonansi magnetik inti (nuclear magnetic resonance, NMR), Liberty, Yogyakarta, 1994 
[14] Carlos Jaime, Javier De Mendoza, Pilar Prados, Pedro M. Nieto, Concha Sanchez, Carbon-13 NMR chemical shifts. A single rule to determine the conformation of calix[4]arenes, The Journal of Organic Chemistry, 56, 10, (1991), 3372-3376 https://doi.org/10.1021/joo0010a036

[15] Gaurav Arora, Calix [4] arenes with protonionizable groups on the lower and upper rim, Dissertation, Texas Tech University, Lubbock, Texas, 2006

[16] C. David Gutsche, Jeffrey A. Levine, P. K. Sujeeth, Calixarenes. 17. Functionalized calixarenes: the Claisen rearrangement route, The Journal of Organic Chemistry, 50, 26, (1985), 5802-5806 https://doi.org/10.1021/j000350a072

[17] C. David Gutsche, Balram Dhawan, Kwang Hyun No, Ramamurthi Muthukrishnan, Calixarenes. 4. The synthesis, characterization, and properties of the calixarenes from p-tert-butylphenol, Journal of the American Chemical Society, 103, 13, (1981), 3782-3792 https://doi.org/10.1021/ja00403a028 